\title{
Entrepreneurship Behavior and Business Competitiveness of Creative Industries
}

\author{
Hari Mulyadi ${ }^{1, *}$ Dian Herdiana Utama ${ }^{2,}$ Jayadi $^{3}{ }^{3}$ Sulastri $^{4}$ \\ ${ }^{1}$ Universitas Pendidikan Indonesia \\ ${ }^{2}$ Universitas Pendidikan Indonesia \\ ${ }^{3}$ Universitas Pendidikan Indonesia \\ ${ }^{4}$ Universitas Pendidikan Indonesia \\ *Corresponding author.Email: harimulyadi@upi.edu
}

\begin{abstract}
The competitiveness factor is one of the economic indicators that is rapidly gaining attention in the global economy. Consequently, some improvement efforts are required to be the primary government's focus in managing the economy. This research aims to find out the description of entrepreneurial behavior, competitiveness, and the effect of entrepreneurial behavior towards competitiveness. It involved descriptive and verification as the approaches. Explanatory survey was selected as a method engaging 117 as respondents. The data were analyzed by using Partial Least Square Path Modelling. The findings of the study revealed that the entrepreneurial behavior description is in the moderate category, while the level of competitiveness is in the high enough category. The entrepreneurial behavior also significantly influences competitiveness.
\end{abstract}

Keywords: Competitiveness; Creative Industries; Entrepreneurial Behavior.

\section{INTRODUCTION}

The ability of nations to join global competence and the free market economy, which requires high productivity, would be decided by the availability of quality human beings who master science and technology. It consequently shifts the main focus onto human capital, technology, and management to improve innovation and competitive advantage in all business and service sectors [1]. The key success of an industry, according to [17], are creating competitive advantage for small business, as well as the aggregation of factors that differentiate small business from their rivals and give them a unique and superior position in the market.

The element of competitiveness is one economic indicator that is rapidly gaining attention in the global economic arena; as a result, efforts to improve competitiveness really is one of the government's primary focuses in managing the economy [2]. In developing countries such as Europe, Japan, and the United States, small businesses have a major impact on the economy [3].

However, in this age of increased competition, the effect on rapid changes in all areas of life, whether economic, social, cultural, science, technological, and so on, is greater [4]. The advancement of national development in general is intended to increase a country's prosperity. This can be done by identifying numerous factors that become the strength of its competitiveness in a world that no longer recognizes borders, including economic, political, and cultural constraints referred to as globalization [5].

Competitiveness refers to an organization's ability to compete in a competitive market against other companies that have the same or similar goods or services. Companies that are capable of delivering high-quality goods or services are successful in the sense that they can compete [6]. The competitiveness of an industry is primarily determined by its goods. Producing goods with a competitive advantage is the company's strategic strategy for surviving or even winning market rivalry [7].

In general, the invention of new products has been recognized as a source of competitive advantage for businesses [8]. Timeliness and the ability to accelerate the process of producing new products are two issues of product growth (Owens \& Davies, 2000).

Moreover, competitiveness is a value proposition that sets a small business apart from its competitors and gives it a unique position in a market that is superior to its 
competitors [16]. Competitiveness can be defined as the ability to maintain market share. This capability is very much determined by good and timely supply factors and competitive prices [9]. [10] explained that competitiveness is the ability of a business owned by a company in the industry in overcoming various environments encountered

The low competitiveness of small businesses in Indonesia is mainly affected by several factors, including marketing, finance, management, technology, location, human resources, and economic structure. These factors can be grouped into internal and external environmental factors [11]. The competitiveness aspect is important in building entrepreneurship and ensuring entrepreneurs to be able to compete as well as meet the needs and desires of customers [12].

In line with this, individuals should be competitive in order to cultivate an entrepreneurial mentality and generate successful entrepreneurs. In addition to the attitude of the entrepreneurs themselves in seizing and properly utilizing opportunities, the government's position in increasing the competitiveness of entrepreneurs is critical. According to [13], the development of an entrepreneur is critical in order to continue to obtain opportunities, compete, expand commerce, and be able to open up job opportunities for others.

In today's competitive climate, companies may have high-quality goods with added value in order to stand out from the competition. Consumers consider quality as one of the factors to consider when purchasing a product [14]. Consumers are willing to pay a premium for high-quality goods, because if the product is of decent quality and consistent, it will stay in their minds for a long time. If a country's industries are competitive, it achieves a competitive advantage [15]. Starting with micro, small, and medium enterprises [16], the effect of a company's inability to compete can affect its growth, and competition has become a challenge for the company. Competitiveness has become a key concept for small, medium, and macro businesses to be able to survive in globalization and free trade [18].

According to [19], companies should provide entrepreneurial creativity in order to compete. Then according [20], innovation refers to adjectives like renewing, modifying, or making a process or product, as well as doing anything to make it more efficient. This can mean introducing new ideas, enhancing current programs, and making other goods more dynamic in a company or business sense.

Based on the background of the above problems, the authors formulate research on the effect of entrepreneurial behavior on competitiveness in the creative industries in Bandung. The purpose of this study was to determine the effect of entrepreneurial behavior on business competitiveness in the creative industries in Bandung

\section{METHODS}

The survey process, also known as an explanatory survey, was used in this analysis. By evaluating hypotheses, this approach aims to evaluate the impact between variables. The creative industry entrepreneur in Bandung is the study's unit of research.

The research included 165 business owners and entrepreneurs (BPS Bandung, 2016). In this analysis, the Slovin sample method was used to sample 117 entrepreneurs/creative business owners in Bandung. Questionnaires were used to gather information for this report. Verification analysis was the data analysis tool used in this research.

\section{RESULTS AND DISCUSSION}

The findings suggest that the owner's entrepreneurial conduct is in fairly good category. According to [21], entrepreneurship is always dedicated to doing its job in order to achieve the desired results, so perseverance, determination, and never giving up are the foundations. The majority of the owners' evaluations of the competitiveness component are in the "fairly good" range. This is the company's strength in terms of being able to compete and gain profits in a long-term manner. Competitiveness is related to the active chain's capacity to deliver long-term benefits. [22].

This research has 2 (two) latent variables with 7 manifest variables. The competitiveness latent variable (Y) consists of 2 (two) manifest variables and the entrepreneurial behavior latent variable $(\mathrm{X})$ consists of 5 (five) manifest variables. The measurement model for each latent variable can be presented as follows.

Exogenous latent variables Competitiveness (Y) can be explained by two dimensions (manifest variable), namely: Products (Y1) and Marketing (Y2). The calculation results for the competitiveness variable measurement model can be described as follows fig. 1 .

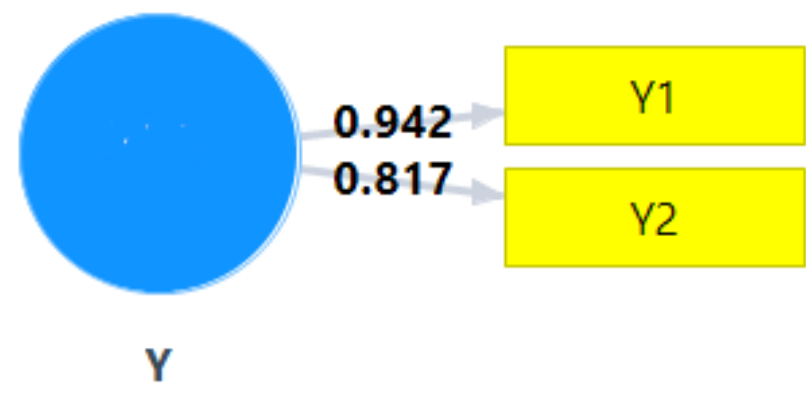

Figure 1 Competitiveness variable measurement model 
The calculation results also showed the value of Cronbach's Alpha $=0.732$; Composite Reliability $=$ 0.874; and Average Variance Extracted $(\mathrm{AVE})=0.778$. All these values indicate that the latent variable measurement model of competitiveness meets the model fit. In other words, all of the manifest variables are valid and reliable in measuring latent competitiveness variables.

Exogenous latent variables Entrepreneurial Behavior (X) can be explained by five dimensions (manifest variable), namely: Personality (X1), Relationship Ability (X2), Marketing Ability (X3), Expertise in Management (X4), and Attitudes towards Money (X5)). The calculation results for the measurement model of the Entrepreneurial Behavior variable can be described as follows fig. 2 .

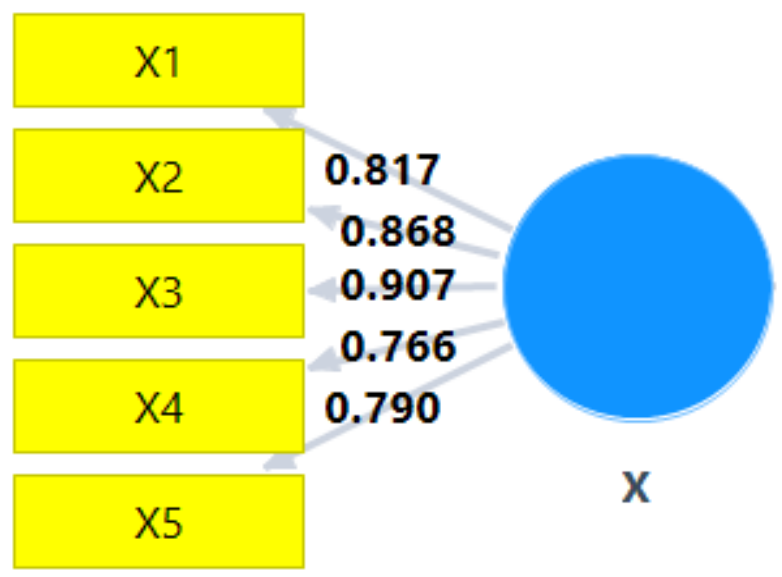

Figure 2 Variable measurement model entrepreneurial behavior

The calculation results showed that all dimensions have a path loading / coefficient $>0.50$ which indicates that each of these dimensions is significantly (meaningful) able to reflect the latent variables of Entrepreneurial Behavior. Through the measurement model test results can be seen the path coefficient of each manifest variable. The estimation of the biggest path coefficient on the latent variable of Entrepreneurial Behavior is stated by Marketing Ability (X3), which shows the strongest dimension in shaping the latent variable Entrepreneurial Behavior in the creative industries in Bandung with loading of 0.907 , followed by Relationship Capability (X2) of 0.868, Personality (X1) of 0.817 , Attitude to money (X5) of 0.790, and finally Expertise (X4) of 0.766 .

The calculation results also show the value of Cronbachs Alpha $=0.887$; Composite Reliability = 0,917; and Average Variance Extracted $(\mathrm{AVE})=0.691$. All of these values indicate that the measurement model for latent variables in Entrepreneurial Behavior already meets the fit model. In other words, all of the manifest variables are valid and reliable in measuring the latent variables of Entrepreneurial Behavior.

Overall, the PLS structural model for the influence of Entrepreneurial Behavior on Competitiveness can be described as follows fig. 3 .

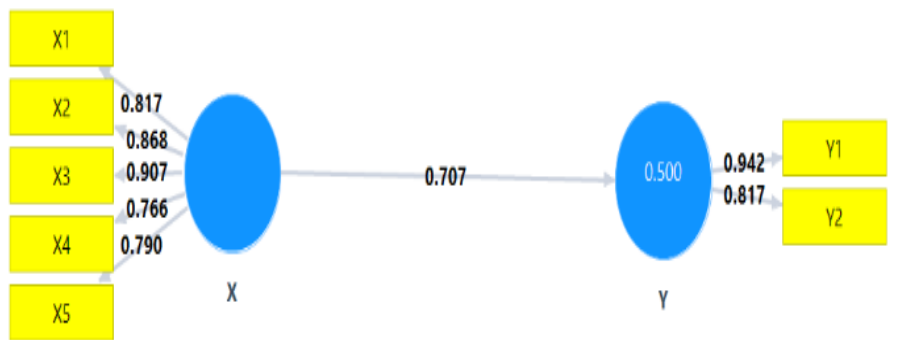

Figure 3. PLS structural model

Structural models are models that connect exogenous latent variables with endogenous latent variables or the relationship of endogenous variables with other endogenous variables. Based on the structural model, the structural equation in this study can be expressed as follows (1)

$\mathrm{Y}=0,707 \mathrm{X}$, with $\mathrm{RSq}=0,500$ and $\mathrm{e}=0,500$

The t-test calculation can be presented as follows fig. 4.

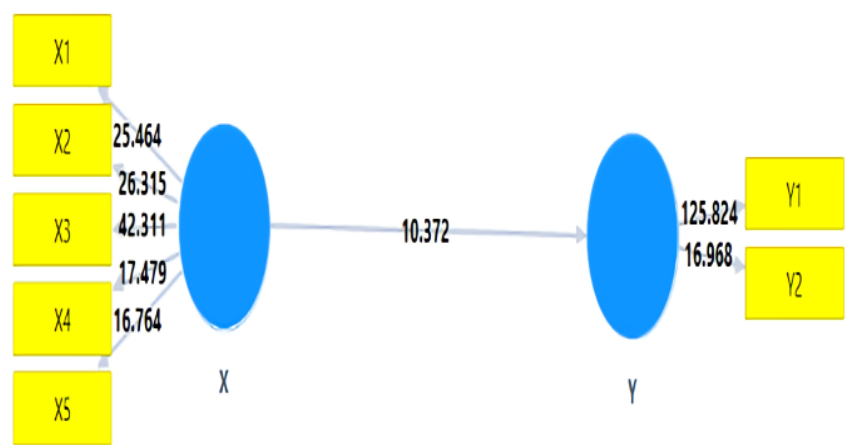

Figure 4 Calculation of t-test

Path calculations and significance for this model can be stated as follows table 1 .

Table 1. Summary of Structural Models

\begin{tabular}{|c|c|c|c|l|l|}
\hline \multicolumn{2}{|c|}{ Model } & lane & $\begin{array}{c}\text { T- } \\
\text { statistik }\end{array}$ & Significance & $\begin{array}{l}\text { Value R2 and } \\
\boldsymbol{e}\end{array}$ \\
\hline $\mathrm{Y}$ & $\mathrm{X} \rightarrow \mathrm{Y}$ & 0,707 & 10,372 & Significance & $\begin{array}{l}\text { RSq }=0,500 ; \\
\mathrm{e}=0,500\end{array}$ \\
\hline
\end{tabular}

Level of Significance $\alpha=0.05$.

Source: Data processing results, 2019

To find out the percentage of the effect of $\mathrm{X}$ on $\mathrm{Y}$, the coefficient of determination can be calculated by using the formula proposed by Riduwan (2013: 136), as follow formula (2).

$\mathrm{KD}=\mathrm{r}^{2} \times 100 \%$ 
The effect of entrepreneurial behavior on competitiveness can be seen from the results of the following table 2 .

Table 2. Coefficient of Determination of Entrepreneurial Behavior Towards Competitiveness

\begin{tabular}{|c|c|c|c|c|}
\hline Model & $\mathbf{R}$ & $\begin{array}{c}\mathbf{R} \\
\text { Square }\end{array}$ & $\begin{array}{c}\text { Adjusted R } \\
\text { Square }\end{array}$ & $\begin{array}{l}\text { Std. Error of } \\
\text { the Estimate }\end{array}$ \\
\hline $\begin{array}{l}\mathrm{X} \\
\mathrm{Y}\end{array}$ & $.707 a$ & .500 & .495 & 0.095 \\
\hline
\end{tabular}

a. Predictors: (Constant), Entrepreneurial Behavior

b. Dependent Variable: Competitiveness

Here are the results of the calculation of the coefficient of determination of $\mathrm{X}$ with respect to $\mathrm{Y}$ :

$$
\begin{aligned}
\mathrm{KD} & =\mathrm{r} 2 \times 100 \% \\
& =(0707) 2 \times 100 \% \\
& =0,500 \times 100 \% \\
& =50,0 \%
\end{aligned}
$$

The correlation coefficient $(\mathrm{R})$ is 0.707 . It means that the relationship between entrepreneurial behavior and competitiveness is 0.707 . From this figure, if it is interpreted, it can be concluded that the relationship between the variables of entrepreneurial behavior with the competitiveness variable is strong.

The F-Square or F2 is used to measure the strength of the predictor variable $(\mathrm{X})$ in explaining endogenous variables (Y). According to Cohen (1988), F2 values of $0.02,0.15$, and 0.35 show weak, moderate and substantial effects. The F2 value obtained in this model is 0.99 , which indicates a substantial effect so that it can be stated that the effect of entrepreneurial behavior on competitiveness is strong.

The results show that the owner's entrepreneurial behavior is in a fairly good category. [21], argues that entrepreneurship is always committed to doing its job to get the expected results, therefore perseverance, persistence, and never give up are the foundation. Most of the owners' assessments of the competitiveness variable are in the fairly good category. This is the strength of the company to be able to compete and earn profits in a sustainable manner. Competitiveness can be linked to the capacity of the productive chain provided for sustainable benefits [22]

The findings of the study support [19] statement that one of the most significant factors affecting market competitiveness is creative entrepreneurial conduct. This can mean introducing new ideas, enhancing current programs, and making other goods more dynamic in a company or business sense. Entrepreneurial conduct encompasses creativity, foresight, and the willingness to take risks.

By gaining confidence, satisfaction, and loyalty, an industrial seller can successfully claim marketing principles and establish a long-term mutually beneficial relationship with his customers [23]. According to [24] study, coaching is based on a behaviorist model in which professional coaches facilitate organizational improvement in order to enhance business efficiency.

Moreover, the findings of the study conducted by [24], entrepreneurial behavior has an effect on business competitiveness, which is reinforced by the findings of [25] research, explaining that one of the factors that can improve business competitiveness is creative and innovative entrepreneurial behavior.

\section{CONCLUSIONS}

The findings of this study and discussion show that the interpretation of entrepreneurial activity based on responses from business owners is very accurate. According to the responses of business owners, the concept of competition is very strong. Entrepreneurial activity influences the competitiveness of entrepreneurs in Bandung's creative industries in a constructive and important way.

Implications: Entrepreneurial activity that falls into the "fairly decent" category would have an effect on the long-term viability of the company if not changed. Personality, relationship skills, marketing skills, organizational skills, and financial management skills must all be strengthened. If the competitiveness of companies in the high enough group does not increase, it will have a negative effect on their long-term profitability. Product and marketing innovation, as well as product and marketing innovation, must be strengthened. Entrepreneurial activity that is still very good would have an effect on the competitiveness of the business. As a result, if a company owner wishes to make a lot of money. According to research, entrepreneurs have a high level of competition, so they must boost or strengthen their entrepreneurial actions.

\section{ACKNOWLEDGMENTS}

On this occasion, we would like to thank the Universitas Pendidikan Indonesia Rector, Universitas Pendidikan Indonesia FPEB Dean for the assistance, motivation and opportunity to the researchers so that this research can be carried out.

\section{REFERENCES}

[1] Hasanah, Entrepreneurship: Membangun jiwa entrepreneur anak melalui pendidikan kejuruan, Makassar: CV. Misvel Aini Jaya, 2015.

[2] Ariyanto, Agroindustri Kelapa Sawit: Dampaknya Terhadap Ekonomi dan Daya Saing Indonesia. Literature Review, 2016. 
[3] Kingma, "Creating a dynamic campus - community entrepreneurial ecosystem: key characteristics of success," Academic Entrepreneurship: Creating an Entrepreneurial Ecosystem, 97-114. https://doi.org/10.1108/S1074$754020140000016003,2014$.

[4] H. Mulyadi and N. Marlina, "Pengaruh motivasi dan disiplin kerja karyawan terhadap kinerja karyawan pada departemen weaving pt. adetex cabang banjaran kab. bandung," Strategic: Jurnal Pendidikan Manajemen Bisnis, 9, 2010.

[5] Asnawi, Produktivitas Rakyat dan Daya Saing Indonesia di Pasar Internasional Sebagai Upaya Mendukung Tercapainya Pembangunan Nasional Anita Asnawi. JIABI, 2(1), 2018

[6] J.Bahtiar, W. J. F. Tumbuan dan I. Trang, "Pengaruh insentif, kepuasan kerja dan daya saing terhadap produktivitas kerja karyawan pada ud," Jepara Karya Furniture, Kecamatan Tuminting. J. EMBA, 6(1), 638-647, 2018.

[7] B. W. Hartanto dan J. A. Manggalarini, "Adaptasi modular funtion deployment untuk kesuksesan pengembangan konsep produk baru sebagai peningkatan daya saing industri kecil," J. Teknik Industri, 13(3), 129-140, 2018.

[8] J. D. Owens, "Why do some uk smes still find the implementation of a new product development process problematical?: an exploratory investigation," Management Decision, 45(2), 235$251,2007$.

[9] P. Anggraeni, Sunarti dan , M. K. Mawardi, "Analisis swot pada umkm keripik tempe amel malang dalam rangka meningkatkan daya saing perusahaan,"J. Administrasi Bisnis (JAB), 43(1), 2017.

[10] M. L. Annisa dan G. Hutasoit, "Pengaruh daya saing destinasi wisata terhadap implementasi revisiting commitmen wisatawan objek wisata di kota palembang," J. Manajemen Dewantara, 1(2), 77$86,2018$.

[11] L. Christopher, J. Wirtz dan J. Mussry, Pemasaran Jasa (edisi 7), Jakarta: Erlangga, 2011.

[12] Y. Ibrahim dan N. Ahmad, "Keusahawanan dan daya saing usahawan melayu di sektor pelancongan," J. Pengajian Melayu, 17, 16-33, 2006.

[13] T. J. Utomo, "Dan persaingan bisnis ritel ( The business environment and the competition of retail business ), 5(1), 70-80, 2010.
[14]C. Kartika, Model pengembangan strategi pembangunan negara maritim melalui elemen aktivasi dan pengembangan teknologi maritim untuk meningkatkan daya saing kemaritiman dan kesejahtaraaan masyarakat maritim dalam asean economic community 2016, 2016.

[15] Scarborough, N. M, Essentials of Entrepreneurship and Small Business Management (8th ed.). Pearson education, 2016.

[16]Norman M., S, Effective small business management: an entrepreneurial approach (10th ed.). Prentice-Hall, 2012

[17] Tulus Tambunan, Umkm di indonesia. (a. Nazwar, ed.). Bogor: Graha Indonesia, 2009.

[18] M. A. Rashim dan Ghina, A "Identifikasi inovasi dan kinerja bisnis dalam meningkatkan daya saing," J. Penelitian Pendidikan, 213-219, 2018.

[19] W. Dhewanto, R. Indradewa, N, W.Ulfah, S. Rahmawati, G. Yoshanti dan G. Zendry, Manajemen Inovasi untuk Usaha Kecil dan Mikro. Bandung: Alfabeta, 2015.

[20] S. K. S. Wong, "The influence of entrepreneurial orientation on product advantage and new product success," J. of Chinese Entrepreneurship, 4(3), 243 262. https://doi.org/10.1108/02656710210415703, 2012.

[21] S.César, S.Veras, T. S.Mozer, R. Messeder, M. A. Conejero and S. Veras, "Hydrogen productive chain in brazil: an analysis of the cimpetitiveness' Drivers. J. of Cleaner. https://doi.org/10.1016/j.jclepro.2018.09.157, 2018.

[22]D. Amyx, S. N. Bhuian dan G. D. Shows, "Customer-salespeople relationship Influence of salespeople entrepreneurial behaviours," https://doi.org/10.1108/MIP-09-2015-0170, 2016.

[23]M. D. Vidal-Salazar, V. Ferrón-Vúlchez and E. Cordón-Pozo, "Coaching: an effective practice for business competitiveness" Competitiveness Review, 22(5), 423-433. https://doi.org/10.1108/10595421211266302, 2012.

[24] S. Hadiati, "Perilaku wirausaha industri keramik berskala kecil untuk meningkatkan daya saing produk di malang," J. Manajemen Dan Kewirausahaan, 10(2), 115-123., 2008.

[25]D. A. Sari dan R. Suprapto, "Strategi peningkatan daya saing umkm penglahan ikan melalui analisis swot,” J. of Management \& Busines, 1(2), 2018. 
[26] S. N. Aisyah, "Generasi peduli buday madura gua meningkatkan daya saing produk batik tanjung bumi dalam menghadapi masyarakat ekonomi asean,” Kompetensi, 11(2), 256-269, 2017.

[27] P. H. Dickson, G. T.Solomon and K. M. Weaver, "Entrepreneurial selection and success: does education matter?," J. of Small Business and Enterprise Development, 15(2), 239-258. https://doi.org/10.1108/14626000810871655, 2008.

[28]H. Frinces, Be an entrepreneur (1st ed.). Yogyakarta: Graha Ilmu, 2011.

[29]B. J. Hicks, S. J. Culley, R. D. Allen and G. Mullineux, (). A Framework for the Requirements of Capturing, Storing and Reusing Information and Knowledge in Engineering Design. International J. of Information Management, 22(4), 263-280, 2002.

[30]H. Mulyadi, G. Razati dan Ramadhanti, D. "Pengaruh status sosial ekonomi orang tua terhadap prestasi belajar siswa," Strategic: J. Pendidikan Manajemen Bisnis, 3, 3-6, 2013.

[31]H. Mulyadi, R. D. H., Utama dan W. Rahayu, "Gambaran sikap kewirausahaan dan niat berwirausaha pada mahasiswi angkatan 2014 di upi bandung," J. of Business Management Education, 3(1), 63-72, 2018.

[32]H. Mulyadi, , B.Widjajanta dan S. P.Aji, "Keterampilan wirausaha untuk keberhasilan usaha," J. of Business Management Education, 3(3), 111-122, 2018.

[33] Nararya dan A. Budianto, "Anak muda bisa menjadi pencipta lapangan kerja. koran sindo," Retrieved from

https://ekbis.sindonews.com/read/1296057/34/anak -muda-bisa-menjadi-pencipta-lapangan-kerja1523152669, 2018, April 8.

[34] Papadopoulou, E. Ineson, D. Williams, A. Papadopoulou, E. Ineson and D. Williams, "Factors involved in the success of hong kong construction and property entrepreneurs sammy, 29(2014). https://doi.org/10.1108/02656710210415703, 2012 "

[35] Riduwan, Cara menggunakan dan memakai analisis jalur (path analysis), Bandung: Alfabeta, 2013.

[36] K. N. Simpeh, "Entrepreneurship theories and empirical research: a summary review of the literature," J. of Business and Management, 3(6), 19, 2011.

[37] Sugiyono, Metode penelitian kuantitatif, kualitatif dan r \& d. Bandung: Alfabeta, 2017.
[38] Suryana, Kewirausahaan: kiat dan proses menuju sukses (4th ed.). Jakarta: Salemba Empat, 2014. 